\title{
Patronal politics: Eurasian regime dynamics in comparative perspective
}

\section{Matthew Frear}

To cite this article: Matthew Frear (2016) Patronal politics: Eurasian regime dynamics in comparative perspective, East European Politics, 32:3, 403-404, DOI: 10.1080/21599165.2016.1184146

To link to this article: https://doi.org/10.1080/21599165.2016.1184146
(c) 2016 The Author(s). Published by Informa UK Limited, trading as Taylor \& Francis Group.
曲 Published online: 19 Jul 2016.

Submit your article to this journal $\pi$

Џ Article views: 336

View Crossmark data 
ə OPEN ACCESS

Patronal politics: Eurasian regime dynamics in comparative perspective, by Henry E. Hale, New York, Cambridge University Press, 2015, 558 pp., £24.99 (paperback), ISBN 978-1-107-42313-8

The full title of Henry Hale's most recent book offers an overview of the structure to follow inside. The opening chapters provide an introduction to and explanation of patronal politics. The middle chapters then apply this to the Eurasian regime dynamics of the post-Soviet republics (excluding the Baltic states) as well as a number of unrecognised, de facto states in the region. The final two chapters take a comparative perspective, within the region itself and globally.

The conceptual groundwork for the book is laid in Chapter 2, in particular distinguishing patronalism from existing concepts including neopatrimonialism, clientelism and informal politics. After some historical context in Chapter 3, in the next two chapters Hale provides the reader with more detail on the main features of patronal politics as a form of "social equilibrium" around which political and economic interests are pursued by individuals, rather than any abstract principles (61).

Chapter 4 introduces the idea of single- or competing-pyramid configurations of patronal networks (64). Dominant patrons take the calculated risk of holding some form of competitive, nationwide elections. Hale argues that many so-called democratic breakthroughs have in fact been evidence of predictable regime cycles, reflecting the reconfiguration of a single-pyramid network arrangement (87-88). Chapter 5 asks who are represented in these networks of personal connections. It highlights oligarchic business patrons and bottom-up, local political machines in particular, but emphasises the risk of oversimplification (115). Hale notes that patronal politics can be very dynamic and can "arrange themselves in different ways at different times" (93). There is no one template that all regimes which practice patronal politics conform to.

In the next five chapters, Hale seeks evidence of patronal politics in the post-Soviet republics of Eurasia. Making up over half the book, this section is one of the real strengths of the work. Rather than selecting a handful of case studies - the usual suspects that might be expected to support Hale's argument - the book covers the 12 post-Soviet republics of Eastern Europe, the South Caucasus and Central Asia, as well as the separatist quasi-states of Transnistria, Abkhazia, South Ossetia and Nagorno-Karabakh. Chapter 6 describes the various trajectories countries followed in the 1990s which culminated in most cases with a single-pyramid patronal network holding power with a strong president at the helm. Chapter 7 identifies 10 instances of the ouster of a president at the top of a patronal network. Hale argues that most of these are consistent with elite-driven regime cycles within patronal networks. Chapter 8 looks at those patronal presidents elsewhere in the region which have consolidated their own long-term rule or successfully managed a planned succession.

Post-revolutionary polities are revisited in Chapter 9 - with an emphasis on Ukraine after the Orange Revolution in 2004 and Euromaidan in 2014, as well as Kyrgyzstan after the Tulip Revolution in 2005 and its bloody successor in 2010. Both illustrate the idea of competing-pyramid patronal networks where there is a divided executive and the potential for rival patrons in the post of president and prime minister. Hale contests that in spite of the appearance of democratising tendencies, patronal instincts amongst elites are likely to prevail after revolutions (370). Finally the outlier, Moldova, is studied in Chapter 10, as a potential case of patronal parliamentarism.

In the final two chapters, Hale summarises his findings and argues that Eurasia is a "pristine paternalistic environment" that demonstrates the significance of personal connections (466). He challenges some of the conventional wisdom on the importance of factors such as civil 
society, international actors or a market economy in regime dynamics. The final chapter argues that the books findings could also be applied elsewhere in the world, with the most discussion devoted to Asia and the Middle East.

With its geographical and temporal breadth of coverage, this work could serve as an excellent textbook for a course on Post-Soviet Politics or the Politics of Russia and Eurasia. It provides an introduction to developments in the entire region, in an engaging and readable manner. In making the case for the idea of patronal politics, one could argue that its variety and diversity opens it up to the charge of being a catch-all concept. Nevertheless, Hale endeavours to avoid conceptual overreach and is careful to acknowledge potential limitations throughout the book. As such it is welcome contribution to the literature on comparative politics.

Matthew Frear

Leiden University, The Netherlands (2) m.j.frear@hum.leidenuniv.nl (1) http://orcid.org/0000-0001-7334-649X

๑ 2016 The Author(s). Published by Informa UK Limited, trading as Taylor \& Francis Group. This is an Open Access article distributed under the terms of the Creative Commons Attribution-NonCommercialNoDerivatives License (http://creativecommons.org/licenses/by-nc-nd/4.0/), which permits non-commercial re-use, distribution, and reproduction in any medium, provided the original work is properly cited, and is not altered, transformed, or built upon in any way. http://dx.doi.org/10.1080/21599165.2016.1184146 